\title{
Crystal chemistry, thermal expansion, and Raman spectra of hydroxyl-clinohumite: implications for water in Earth's interior
}

\author{
Yu Ye $\cdot$ Joseph R. Smyth $\cdot$ Steven D. Jacobsen • \\ Céline Goujon
}

Received: 18 July 2012/ Accepted: 18 October 2012/Published online: 9 November 2012

(C) Springer-Verlag Berlin Heidelberg 2012

\begin{abstract}
Two samples of hydroxyl-clinohumite, sample SZ0407B with approximate composition $\mathrm{Mg}_{8.674(14)}$ $\mathrm{Fe}_{0.374(4)}\left(\mathrm{Si}_{0.99(1)} \mathrm{O}_{4}\right)_{4}(\mathrm{OH})_{2}$ and sample SZ0411B with composition $\mathrm{Mg}_{9}\left(\mathrm{SiO}_{4}\right)_{4}(\mathrm{OH})_{2}$, were synthesized at $12 \mathrm{GPa}$ and $1,250{ }^{\circ} \mathrm{C}$ coexisting with olivine. Unit-cell parameters determined by single-crystal $\mathrm{X}$-ray diffraction are given as follows: $a=4.7525(4) \AA, b=10.2935(12) \AA$, $c=13.7077(10) \AA, \alpha=100.645(9)^{\circ}, V=659.04(9) \AA^{3}$ for SZ0407B, and $a=4.7518(6) \AA, \quad b=10.2861(12) \AA$, $c=13.7008(9) \AA, \alpha=100.638(9)^{\circ}, V=658.15(9) \AA^{3}$ for SZ0411B. Single-crystal X-ray intensity data were
\end{abstract}

Communicated by T. L. Grove.

Electronic supplementary material The online version of this article (doi:10.1007/s00410-012-0823-8) contains supplementary material, which is available to authorized users.

Y. Ye $(\bowtie)$

Department of Physics, University of Colorado, Boulder, CO 80309, USA

e-mail: yuye1@asu.edu

Present Address:

$\mathrm{Y}$. Ye

School of Earth and Space Exploration, Arizona State

University, Tempe, AZ 85287, USA

J. R. Smyth

Department of Geological Sciences, University of Colorado, Boulder, CO 80309, USA

\section{S. D. Jacobsen}

Department of Earth and Planetary Sciences, Northwestern University, Evanston, IL 60208, USA

C. Goujon Institut Néel, CNRS et Université Joseph Fourier, BP 166, 38042 Grenoble Cedex 9, France collected for crystal structure refinements of both samples. Relative to the pure-Mg sample, Fe decreases M3-OH bond lengths by $\sim 0.010(3) \AA$, consistent with some ferric iron ordering into M3. Raman spectroscopy shows two strong bands in the lattice-mode region at 650 and $690 \mathrm{~cm}^{-1}$ in the Fe-bearing sample, which are not observed in the pure- $\mathrm{Mg}$ sample. Spectra in the $\mathrm{H}_{2} \mathrm{O}$ region show at least five bands, which are deconvolved into seven distinct $\mathrm{O}-\mathrm{H}$-stretching modes. Thermal expansion measurements were carried out for both samples from 153 to $787 \mathrm{~K}$ by single-crystal X-ray diffraction. The average $a-, b-, c$-axial and volumetric thermal expansion coefficients $\left(10^{-6} \mathrm{~K}^{-1}\right)$ are 10.5(1), 12.3(2), 12.5(2) and 34.9(5) for SZ0407B, respectively, and 11.1(1), 12.6(3), 13.7(3), 36.8(6) for SZ0411B, respectively. After heating, the unit-cell parameters were refined again for each sample at ambient condition, and no significant changes were observed, indicating no significant oxidation or dehydration during the experiment. For the DHMS phases along the brucite-forsterite join, linear regression gives a systematic linear decrease in expansivity with increasing density. Further, substitution of ferrous iron into these structures decreases thermal expansivity, making the Fe-bearing varieties slightly stiffer.

Keywords Clinohumite - Crystal structure $\cdot$ Thermal expansion · Iron effect

\section{Introduction}

The dense hydrous magnesium silicate (DHMS) minerals along the brucite $(\mathrm{Br})$-forsterite ( $\mathrm{Fo}$ ) join have been widely studied and proposed as potential carriers of water into the Earth's mantle (McGetchin et al., 1970; Wunder et al., 1995; Kanzaki 1991; Faust and Knittle 1994). These minerals could 
also be reservoirs for $\mathrm{H}_{2} \mathrm{O}$ in the upper mantle and transition zone in extremely hydrous compositions. These phases include Phase A ( $\left.2 \mathrm{Fo}+3 \mathrm{Br}, 12 \mathrm{wt} \% \mathrm{H}_{2} \mathrm{O}\right)$, norbergite (1 $\left.\mathrm{Fo}+1 \mathrm{Br}, 9 \mathrm{wt} \% \mathrm{H}_{2} \mathrm{O}\right)$, chondrodite $(2 \mathrm{Fo}+1 \mathrm{Br}, 5 \mathrm{wt} \%$ $\mathrm{H}_{2} \mathrm{O}$ ), humite ( $\left.3 \mathrm{Fo}+1 \mathrm{Br}, 4 \mathrm{wt} \% \mathrm{H}_{2} \mathrm{O}\right)$, and clinohumite (4 $\mathrm{Fo}+1 \mathrm{Br}, \quad 3 \mathrm{wt} \% \quad \mathrm{H}_{2} \mathrm{O}$ ). Among these, Phase A $\left(\mathrm{Mg}_{7} \mathrm{Si}_{2} \mathrm{O}_{8}(\mathrm{OH})_{6}\right)$, chondrodite $\left(\mathrm{Mg}_{7} \mathrm{Si}_{2} \mathrm{O}_{8}(\mathrm{OH})_{6}\right)$, and clinohumite $\left(\mathrm{Mg}_{9} \mathrm{Si}_{4} \mathrm{O}_{16}(\mathrm{OH})_{2}\right)$ have been observed as dehydration products of serpentine and in experimental studies of pure $\mathrm{MgO}-\mathrm{SiO}_{2}-\mathrm{H}_{2} \mathrm{O}$ systems at pressures of 5 to 12 GPa (Wunder 1998; Berry and James 2001; Smyth et al. 2006). In the current study, we focus on two synthetic samples of $\mathrm{Mg}$-pure and Fe-bearing ( $\mathrm{Fe} \%=4 \mathrm{~mol} \%$ ) F-free clinohumite by single-crystal X-ray diffraction. In natural high-grade metamorphic rocks and carbonates, clinohumite typically contains $\mathrm{F}$ at the hydroxyl site and $\mathrm{Ti}$ in one of the octahedral sites. Ferraris et al. (2000) report a natural sample with $\mathrm{OH}$ dominant in the $\mathrm{OH}$ position. Crystal structure studies have been reported for various clinohumite samples: Ottolini et al. (2000) for natural F-bearing clinohumite, Berry and James (2001) for synthetic Mg-pure clinohumite, and Friedrich et al. (2001) for natural titano-clinohumite by neutron diffraction. Only the monoclinic members of the humite series, clinohumite and chondrodite, have been reported from high-pressure experiments in F-free compositions.

The crystal structure of clinohumite is illustrated in Fig. 1. The space group is $P 2_{1} / b$, which is a nonstandard setting of $P 2_{1} / c$ chosen to preserve the structural similarity to olivine, so that the $a$ and $b$ axes of olivine and clinohumite are approximately the same. The structure consists of two distinct $\mathrm{Si}$ tetrahedral sites, $\mathrm{Si} 1$ and $\mathrm{Si} 2$, and five distinct octahedral sites, labeled M1c, M1n, M2-5, M2-6, and M3 (Fig. 1). There are nine distinct oxygen positions, each bonded to one $\mathrm{Si}$ and three octahedral cations as in olivine, except one monovalent anion site termed $\mathrm{OFOH}$, bonded to three octahedral cations. There are two proton $(\mathrm{H})$ positions possible in F-free clinohumite, one of which is so close to the inversion center that it cannot be fully occupied, so a second position is possible (Berry and James 2001). If present, $\mathrm{Ti}$ is strongly ordered into the M3 position to relieve the need for the second proton position and reduce the volume of both the M3 octahedron as well as the unit cell.

In order to evaluate the possible role of clinohumite in subduction environments, it is necessary to have constraints on the equations of state of dense hydrous magnesium silicate phases that might occur in subduction environments as a result of the dehydration of serpentine. Much work has been done on the compressibilities and elasticities of these DHMS phases (Ross and Crichton 2001; Holl et al. 2006; Sanchez-Valle et al. 2006), as well as the thermal expansivities of brucite (Fukui et al. 2003), Phase A (Pawley et al. 1995), and forsterite (Ye et al. 2009). Here, we investigate the effect of iron on the Raman

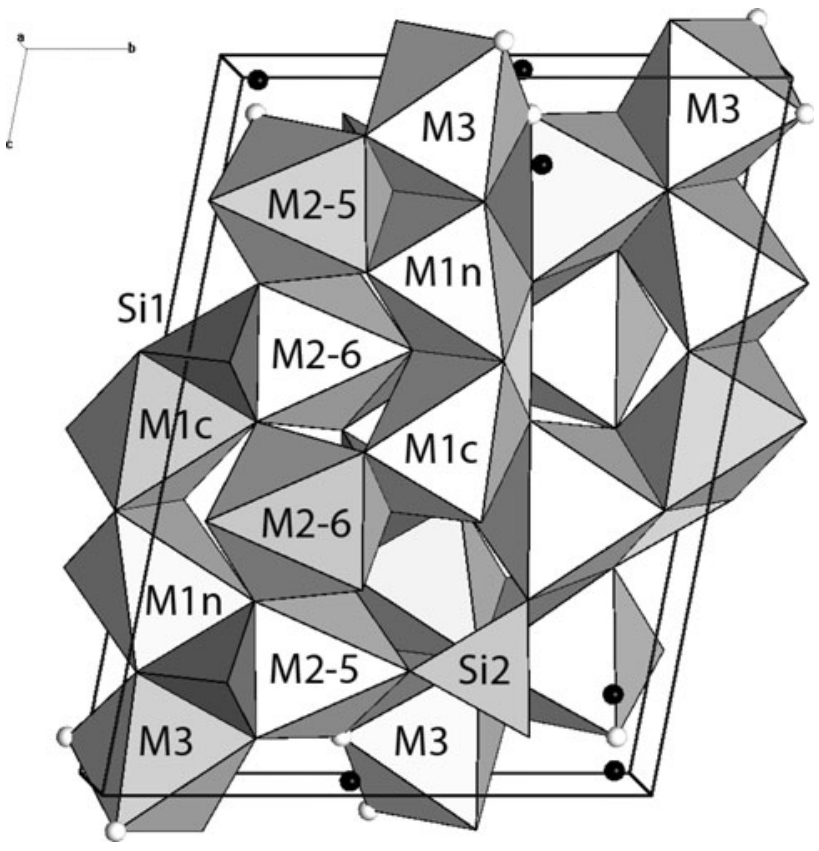

Fig. 1 Crystal structure clinohumite viewed approximately down $a$. The hydroxyl oxygen position is shown as a white sphere. The two proton positions are shown as black spheres

spectra, thermal expansion, and thermal stability of hydroxyl-clinohumite. Ross and Crichton (2001) showed that the compressibility decreases linearly with increasing density from brucite to forsterite. Here, we show that thermal expansivity also decreases linearly with density along the brucite-forsterite join. We also present crystal structure refinements of two $\mathrm{OH}$-clinohumite samples synthesized at $12 \mathrm{GPa}$ and $1,250{ }^{\circ} \mathrm{C}$ : one end-member sample of nominal formula $\mathrm{Mg}_{9}\left(\mathrm{SiO}_{4}\right)_{4}(\mathrm{OH})_{2}$ and another containing minor amounts of $\mathrm{Fe}, \mathrm{Mn}, \mathrm{Ni}, \mathrm{Ti}, \mathrm{Ca}$, and $\mathrm{Al}$.

\section{Experimental procedures}

Sample synthesis and composition

The sample SZ0411B is Mg-pure clinohumite, and we assume the stoichiometric composition to be $\mathrm{Mg}_{9} \mathrm{Si}_{4} \mathrm{O}_{18} \mathrm{H}_{2}$, whereas the composition of the Fe-bearing sample SZ0407B was analyzed by electron microprobe. Both samples were synthesised at $12 \mathrm{GPa}$ and $1,250{ }^{\circ} \mathrm{C}$ in double-capsule experiments with two 1.2-mm-diameter welded Pt inner capsules inside a 2-mm outer capsule with the space between capsules packed with brucite to prevent $\mathrm{H}$ loss. The two inner capsules had compositions of differing silica activity, one with lower silica giving an assemblage of olivine plus clinohumite and the other giving an assemblage of olivine plus clinoenstatite (Smyth et al. 2006). Starting material for sample SZ0407B was San 
Carlos olivine plus silica plus brucite and that for sample SZ0411B was synthetic forsterite, plus silica plus brucite. Sample SZ0407B also contained a small amount of chondrodite which may have resulted from incomplete equilibration between the natural olivine and brucite in the starting material. Oxygen fugacity was not directly buffered during the experiment.

A single crystal about $150 \mu \mathrm{m}$ from sample SZ0407B was chosen for chemical analysis by electron microprobe. The sample was mounted in epoxy and polished on the surface. Mineral compositions were analyzed using a JEOL 8600 SuperProbe, operating at a $15 \mathrm{kV}$ accelerating voltage and $20 \mathrm{nA}$ beam current, with a $5 \mu \mathrm{m}$ beam size. Certified mineral standards were used (olivine for $\mathrm{Mg}, \mathrm{Fe}$ and $\mathrm{Si}$, nickel metal for $\mathrm{Ni}$, garnet for $\mathrm{Mn}$ and $\mathrm{Al}$, wollastonite for $\mathrm{Ca}$, ilmenite for $\mathrm{Ti}$ ). Eighteen points were selected for measuring the weight percentages of oxides, and the average values with standard deviations are listed in Table 1 , as well as the weight percentage of $\mathrm{H}_{2} \mathrm{O}$, which was calculated assuming the mole ratio of $\mathrm{H}: \mathrm{O}$ to be $2: 18$. The water content is $2.84 \mathrm{wt} \%$ for Fe-bearing OH-clinohumite and $2.90 \mathrm{wt} \%$ for $\mathrm{Mg}$-pure $\mathrm{OH}$-clinohumite. The formula of sample SZ0407B is summarized as follows: $\mathrm{Mg}_{8.674} \mathrm{Fe}_{0.374} \mathrm{Ti}_{0.001} \mathrm{Mn}_{0.005} \mathrm{Ni}_{0.011} \mathrm{Al}_{0.007} \mathrm{Ca}_{0.001} \mathrm{Si}_{3.961} \mathrm{O}_{18} \mathrm{H}_{2}$, which indicates $\mathrm{Fe} /(\mathrm{Fe}+\mathrm{Mg})=0.041$.

\section{Raman spectroscopy}

The same $\mathrm{OH}$-clinohumite crystals used for room-temperature X-ray diffraction experiments were prepared for Raman spectroscopy. Both pure-Mg (run SZ0411B) and Fe-bearing (SZ0407B) OH-clinohumite samples were measured, along with a crystal of $\mathrm{OH}$-chondrodite from SZ0407B for comparison. Crystals were 100-150 $\mu \mathrm{m}$ in size, unpolished, and unoriented. The crystals were cleaned

Table 1 Results of electron microprobe analyses for SZ0407B, compared with calculated results for SZ0411B $\left(\mathrm{Mg}_{9} \mathrm{Si}_{4} \mathrm{O}_{18} \mathrm{H}_{2}\right)$

\begin{tabular}{lcllll}
\hline & $\mathrm{SZ0407B}^{2}$ & $\mathrm{SZ0411B}^{\mathrm{a}}$ & & $\mathrm{SZ0407B}$ & SZ0411B $^{\mathrm{a}}$ \\
\hline $\begin{array}{l}\mathrm{SiO}_{2} \\
(\mathrm{wt} \%)\end{array}$ & $37.53(9)$ & 38.70 & $\mathrm{Si}$ & $3.961(9)$ & 4 \\
$\mathrm{TiO}_{2}$ & $0.014(4)$ & - & $\mathrm{Ti}$ & $0.0011(3)$ & - \\
$\mathrm{Al}_{2} \mathrm{O}_{3}$ & $0.053(2)$ & - & $\mathrm{Al}$ & $0.0066(2)$ & - \\
$\mathrm{MgO}$ & $55.12(9)$ & 58.40 & $\mathrm{Mg}$ & $8.674(14)$ & 9 \\
$\mathrm{FeO}$ & $4.24(5)$ & - & $\mathrm{Fe}$ & $0.374(4)$ & - \\
$\mathrm{NiO}$ & $0.131(6)$ & - & $\mathrm{Ni}$ & $0.011(1)$ & - \\
$\mathrm{MnO}$ & $0.057(2)$ & - & $\mathrm{Mn}$ & $0.0051(2)$ & - \\
$\mathrm{CaO}$ & $0.008(2)$ & - & $\mathrm{Ca}$ & $0.0008(2)$ & - \\
$\mathrm{H}_{2} \mathrm{O}^{\mathrm{b}}$ & 2.84 & 2.90 & $\mathrm{H}^{\mathrm{b}}$ & 2 & 2 \\
$\mathrm{Total}^{\mathrm{b}}$ & $100.00(3)$ & 100 & & & \\
\hline
\end{tabular}

${ }^{a}$ Data for SZ0411B are calculated from stoichiometry

b The wt $\%$ and apfu values for $\mathrm{H}_{2} \mathrm{O} / \mathrm{H}$ are calculated from stoichiometry, assuming the mole ratio of $\mathrm{H}: \mathrm{O}$ to be $2: 18$ in acetone prior to Raman measurements in order to remove any glue or grease left on the samples from the diffraction mounts. For each composition, unpolarized spectra were obtained from two different, nearly orthogonal directions in the crystals, subsequently called orientation 1 (OR1) and orientation 2 (OR2).

Raman spectra were obtained using a 457-nm diodepumped, solid-state laser (Melles Griot 85-BLS-601) operating at $250 \mathrm{~mW}$ output. Neutral density filters were used to reduce the power to about $2.5 \mathrm{~mW}$ at the sample, focused to $<5 \mu \mathrm{m}$ spot size through a $100 \times$ objective with a numerical aperture of 0.7. A confocal setup around an Olympus-BX microscope is interfaced with a 0.3 meter Andor Shamrock 303 spectrograph and Newton DU-970 electron multiplying CCD camera (EMCCD). Excitation with a 457-nm source puts bands in the $\mathrm{OH}$-stretching region $\left(3,000-3,600 \mathrm{~cm}^{-1}\right.$ shift) at around $530-550 \mathrm{~nm}$, which is where our EMCCD has the highest quantum efficiency. Spectra were collected either using 1,200 lines/mm or 1,800 lines/mm diffraction gratings. All the spectra were collected using a 60-s acquisition time, averaged over five accumulations.

\section{Crystal structure}

Two single crystals from the samples of SZ0407B and SZ0411B were selected for X-ray intensity measurements at ambient conditions, and crystal sizes were about $110 \times 100 \times 90 \mu^{3}$ for SZ0407B; $110 \times 95 \times 80 \mu \mathrm{m}^{3}$ for SZ0411B. First, the unit-cell parameters of each crystal were refined using a Bruker $\mathrm{P} 4$ four-circle diffractometer with a dual scintillation point detector system, which used an $18 \mathrm{~kW}$ rotating Mo-anode X-ray generator operated at $50 \mathrm{kV}$ and $250 \mathrm{~mA}$. MoK$\alpha_{1}-K \alpha_{2}$ mixed characteristic wavelength was used with $K \alpha \_$avg $=0.71080 \AA$, which was calibrated by a single crystal of anhydrous forsterite of spherical shape. In total, diffractometer angles for 40 reflections were refined, with unique indices $(0 \overline{2} 1),(0 \overline{2} 2)$,

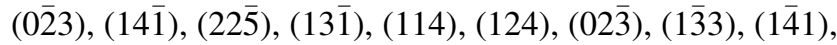

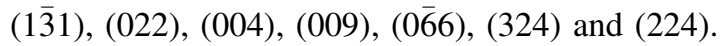

Intensity data for both single crystals were collected using a Bruker APEX II CCD detector mounted on a P4 diffractometer, with the $2 \theta$ scan ranges $<60^{\circ}$. Refinements of atom positions and anisotropic displacement parameters were done using the program SHELXL-97 (Sheldrick 1997) in the software package WinGX (Farrugia 1999). We used scattering factors of $\mathrm{Mg}^{2+}, \mathrm{Fe}^{2+}$ and $\mathrm{Si}^{4+}$ reported by Cromer and Mann (1968), and those of $\mathrm{O}^{2-}$ from Tokonami (1965). Friedrich et al. (2001) reported only one proton position in the crystal structures of natural F-bearing clinohumite samples by single-crystal neutron diffraction, whereas Berry and James (2001) observe two deuterium positions (D1 and D2) in the internal structure of synthetic 
Table 2 Unit-cell parameters and intensity data collection parameters at ambient condition

\begin{tabular}{lcclll}
\hline & SZ0407B & SZ0411B & & SZ0407B & SZ0411B \\
\hline$a(\AA)$ & $4.7525(4)$ & $4.7518(6)$ & No. total reflections & 9,222 & 8,962 \\
$b(\AA)$ & $10.2935(12)$ & $10.2861(12)$ & No. unique total & 1,933 & 1,963 \\
$c(\AA)$ & $13.7077(10)$ & $13.7008(9)$ & No. unique $I>4 \sigma$ & 1,604 & 1,323 \\
$\alpha\left({ }^{\circ}\right)$ & $100.645(9)$ & $100.638(9)$ & GooF & 0.744 & 0.877 \\
$V\left(\AA^{3}\right)$ & $659.04(9)$ & $658.15(9)$ & $R_{1}$ for all $(\%)$ & 3.26 & 6.87 \\
& & & $R_{1}$ for I $>4 \sigma(\%)$ & 2.42 & 3.83 \\
& & & $\mathrm{R}_{\text {int }}(\%)$ & 2.49 & 4.95 \\
\hline
\end{tabular}

deuterated F-free clinohumite sample by powder neutron diffraction. For both the current samples SZ0407B and SZ0411B, we attempted to refine $\mathrm{H} 1$ and $\mathrm{H} 2$ positions, assuming full occupancies in proton positions, and isotropic vibration of protons with $U_{\text {eq }}$ fixed at 0.05 . However, the contribution of $\mathrm{H}$ cations to the $\mathrm{X}$-ray reflection intensities is very small, causing little effect on the refinements of the positions for other heavier atoms. The intensity data collection parameters for both samples are listed in Table 2, as well as the unit-cell parameters at ambient condition, and the refined atomic position coordinates and occupancy factors are shown in Table 3, and the anisotropic displacement parameters are listed in Table 4. In Table 3, the refined occupancies of $\mathrm{Mg}, \mathrm{Fe}$ cations for the sample SZ0407B are shown, assuming the total occupancy of $\mathrm{Mg}+\mathrm{Fe}$ to be 1 at each octahedral site. Since the electron microprobe results give an average occupancy of $99 \%$ for $\mathrm{Si}$ in SZ0407B structure, the Si occupancies in the tetrahedral sites are refined for both the samples. In addition, the occupancies of all $\mathrm{O}^{2-}$ anions are fixed at 1 . The cif files for structure refinements of both samples are deposited in the supplementary materials: MOESM1 and MOESM2.

Thermal expansion

After structure refinement at ambient conditions, both single crystals were used for thermal expansion studies at low and high temperatures at ambient pressure. At each temperature step, the unit-cell parameters were refined using the same procedure at ambient temperature described above. Three low-temperature measurements were conducted at 253, 203, and $153 \mathrm{~K}$. Low temperatures were measured and controlled by an LT-2A controller, which uses a low-temperature $\mathrm{N}_{2}$ gas stream. Next, the single crystals were transferred inside silica glass capillary for high-temperature experiments. Ten high-temperature steps were taken for measurements, up to $787 \mathrm{~K}$, using a Bruker high-temperature device, which uses a two-prong ceramic-coated $\mathrm{Pt}$ wire radiant heater, with an Omega temperature-control unit. Ye et al. (2009) reported the temperature calibrations in details. The unit-cell parameters at temperatures are listed in Appendix 1.
Table 3 Atomic position coordinates and occupancy factors

\begin{tabular}{|c|c|c|c|c|c|}
\hline & \multirow[t]{2}{*}{$x$} & \multirow[t]{2}{*}{$y$} & \multirow[t]{2}{*}{$z$} & \multicolumn{2}{|c|}{ Refined occupancy } \\
\hline & & & & $\mathrm{Mg}$ & $\mathrm{Fe}$ \\
\hline \multicolumn{6}{|c|}{$S Z 0407 B$} \\
\hline M1C & 0.5 & 0 & 0.5 & $0.973(4)$ & $0.027(4)$ \\
\hline $\mathrm{M} 1 \mathrm{~N}$ & $0.4952(1)$ & $0.94692(5)$ & $0.27538(4)$ & $0.963(3)$ & $0.037(3)$ \\
\hline M25 & $0.0079(1)$ & $0.14254(5)$ & $0.17177(4)$ & $0.968(3)$ & $0.032(3)$ \\
\hline M26 & $0.5087(1)$ & $0.25066(5)$ & $0.38852(4)$ & $0.972(3)$ & $0.028(3)$ \\
\hline M3 & $0.4882(1)$ & $0.87609(5)$ & $0.04227(4)$ & $0.955(3)$ & $0.045(3)$ \\
\hline Si1 & $0.0730(1)$ & $0.06692(4)$ & $0.39015(3)$ & \multicolumn{2}{|c|}{$0.978(4)$} \\
\hline $\mathrm{Si} 2$ & $0.0782(1)$ & $0.17314(4)$ & $0.83357(3)$ & \multicolumn{2}{|c|}{$0.990(4)$} \\
\hline O11 & $0.7329(2)$ & $0.0649(1)$ & $0.38859(8)$ & & \\
\hline $\mathrm{O} 12$ & $0.2794(2)$ & $0.4205(1)$ & $0.38853(9)$ & & \\
\hline O13 & $0.2228(2)$ & $0.1136(1)$ & $0.29428(9)$ & & \\
\hline $\mathrm{O} 14$ & $0.2221(2)$ & $0.1588(1)$ & $0.48669(9)$ & & \\
\hline $\mathrm{O} 21$ & $0.2387(2)$ & $0.3250(1)$ & $0.16481(8)$ & & \\
\hline $\mathrm{O} 22$ & $0.7753(2)$ & $0.9713(1)$ & $0.16454(9)$ & & \\
\hline $\mathrm{O} 23$ & $0.7254(2)$ & $0.2818(1)$ & $0.26350(9)$ & & \\
\hline $\mathrm{O} 24$ & $0.7283(2)$ & $0.2298(1)$ & $0.07223(9)$ & & \\
\hline $\mathrm{OFOH}$ & $0.2635(3)$ & $0.0487(1)$ & $0.0584(1)$ & & \\
\hline H1 & $0.098(13)$ & $0.004(7)$ & $0.023(5)$ & & \\
\hline $\mathrm{H} 2$ & $0.452(14)$ & $0.101(6)$ & $0.130(5)$ & & \\
\hline \multicolumn{6}{|c|}{$S Z 0411 B$} \\
\hline M1C & 0.5 & 0 & 0.5 & & \\
\hline M1N & $0.4949(2)$ & $0.9471(1)$ & $0.27533(7)$ & & \\
\hline M25 & $0.0071(2)$ & $0.1430(1)$ & $0.17218(7)$ & & \\
\hline M26 & $0.5083(2)$ & $0.2507(1)$ & $0.38875(7)$ & & \\
\hline M3 & $0.4875(2)$ & $0.8751(1)$ & $0.04259(7)$ & & \\
\hline Si1 & $0.0727(2)$ & $0.06683(8)$ & $0.39015(6)$ & \multicolumn{2}{|c|}{$0.987(5)$} \\
\hline $\mathrm{Si} 2$ & $0.0786(2)$ & $0.17287(8)$ & $0.83331(6)$ & \multicolumn{2}{|c|}{$0.993(5)$} \\
\hline O11 & $0.7331(4)$ & $0.0655(2)$ & $0.3885(1)$ & & \\
\hline $\mathrm{O} 12$ & $0.2794(4)$ & $0.4208(2)$ & $0.3886(1)$ & & \\
\hline O13 & $0.2234(4)$ & $0.1133(2)$ & $0.2945(1)$ & & \\
\hline $\mathrm{O} 14$ & $0.2229(4)$ & $0.1584(2)$ & $0.4865(1)$ & & \\
\hline $\mathrm{O} 21$ & $0.2391(4)$ & $0.3252(2)$ & $0.1648(1)$ & & \\
\hline $\mathrm{O} 22$ & $0.7748(4)$ & $0.9715(2)$ & $0.1646(1)$ & & \\
\hline $\mathrm{O} 23$ & $0.7248(4)$ & $0.2823(2)$ & $0.2637(1)$ & & \\
\hline $\mathrm{O} 24$ & $0.7278(4)$ & $0.2295(2)$ & $0.0726(1)$ & & \\
\hline $\mathrm{OFOH}$ & $0.2643(5)$ & $0.0495(2)$ & $0.0589(2)$ & & \\
\hline H1 & $0.13(2)$ & $0.007(10)$ & $0.030(7)$ & & \\
\hline $\mathrm{H} 2$ & $0.48(2)$ & $0.109(9)$ & $0.147(7)$ & & \\
\hline
\end{tabular}


Table 4 Anisotropic displacement parameters $\left(\AA^{2}\right)$

\begin{tabular}{|c|c|c|c|c|c|c|c|}
\hline & $U_{11}$ & $U_{22}$ & $U_{33}$ & $U_{23}$ & $U_{13}$ & $U_{12}$ & $U_{\text {eq }}$ \\
\hline \multicolumn{8}{|c|}{$S Z 0407 B$} \\
\hline M1C & $0.0058(4)$ & $0.0086(4)$ & $0.0060(4)$ & $0.0020(3)$ & $-0.0008(3)$ & $-0.0004(3)$ & $0.0067(3)$ \\
\hline M1N & $0.0060(3)$ & $0.0082(3)$ & $0.0066(3)$ & $0.0002(2)$ & $0.0007(2)$ & $0.0003(2)$ & $0.0071(2)$ \\
\hline M25 & $0.0087(3)$ & $0.0070(3)$ & $0.0079(3)$ & $0.0016(2)$ & $-0.0008(2)$ & $0.0001(2)$ & $0.0078(2)$ \\
\hline M26 & $0.0073(3)$ & $0.0058(3)$ & $0.0074(3)$ & $0.0012(2)$ & $-0.0004(2)$ & $-0.0004(2)$ & $0.0068(2)$ \\
\hline M3 & $0.0076(3)$ & $0.0100(3)$ & $0.0077(3)$ & $0.0022(2)$ & $-0.0004(2)$ & $0.0007(2)$ & $0.0084(2)$ \\
\hline Si1 & $0.0039(2)$ & $0.0054(2)$ & $0.0055(3)$ & $0.0009(2)$ & $-0.0002(1)$ & $-0.0001(1)$ & $0.0050(2)$ \\
\hline $\mathrm{Si} 2$ & $0.0043(2)$ & $0.0052(2)$ & $0.0057(3)$ & $0.0009(2)$ & $-0.0001(1)$ & $0.0000(1)$ & $0.0051(2)$ \\
\hline O11 & $0.0053(6)$ & $0.0073(5)$ & $0.0067(6)$ & $0.0012(4)$ & $0.0010(4)$ & $0.0001(4)$ & $0.0064(3)$ \\
\hline $\mathrm{O} 12$ & $0.0064(5)$ & $0.0069(5)$ & $0.0069(6)$ & $0.0010(4)$ & $0.0000(4)$ & $0.0012(4)$ & $0.0068(3)$ \\
\hline $\mathrm{O} 13$ & $0.0064(6)$ & $0.0074(5)$ & $0.0062(6)$ & $0.0022(4)$ & $0.0004(4)$ & $0.0004(4)$ & $0.0065(3)$ \\
\hline $\mathrm{O} 14$ & $0.0066(6)$ & $0.0063(5)$ & $0.0078(6)$ & $0.0006(4)$ & $0.0001(4)$ & $0.0000(4)$ & $0.0070(3)$ \\
\hline $\mathrm{O} 21$ & $0.0055(6)$ & $0.0077(5)$ & $0.0064(6)$ & $0.0009(4)$ & $0.0000(4)$ & $0.0003(4)$ & $0.0066(3)$ \\
\hline $\mathrm{O} 22$ & $0.0074(6)$ & $0.0066(5)$ & $0.0075(6)$ & $0.0013(4)$ & $0.0006(4)$ & $0.0002(4)$ & $0.0072(3)$ \\
\hline $\mathrm{O} 23$ & $0.0060(5)$ & $0.0077(5)$ & $0.0071(6)$ & $0.0022(4)$ & $0.0003(4)$ & $0.0001(4)$ & $0.0068(3)$ \\
\hline $\mathrm{O} 24$ & $0.0071(6)$ & $0.0061(5)$ & $0.0067(6)$ & $0.0000(4)$ & $0.0001(4)$ & $-0.0002(4)$ & $0.0068(3)$ \\
\hline $\mathrm{OFOH}$ & $0.0170(7)$ & $0.0084(6)$ & $0.0199(7)$ & $0.0044(5)$ & $0.0111(6)$ & $0.0036(5)$ & $0.0149(3)$ \\
\hline \multicolumn{8}{|c|}{ SZ0411B } \\
\hline M1C & $0.0059(7)$ & $0.0103(7)$ & $0.0062(6)$ & $0.0019(5)$ & $-0.0009(5)$ & $0.0003(6)$ & $0.0074(3)$ \\
\hline M1N & $0.0069(5)$ & $0.0081(5)$ & $0.0077(4)$ & $-0.0007(4)$ & $0.0005(4)$ & $0.0004(4)$ & $0.0078(2)$ \\
\hline M25 & $0.0088(5)$ & $0.0067(5)$ & $0.0085(5)$ & $0.0008(4)$ & $-0.0006(4)$ & $-0.0002(4)$ & $0.0080(3)$ \\
\hline M26 & $0.0066(5)$ & $0.0058(5)$ & $0.0086(5)$ & $0.0008(4)$ & $0.0002(4)$ & $-0.0006(4)$ & $0.0071(2)$ \\
\hline M3 & $0.0079(5)$ & $0.0093(5)$ & $0.0096(5)$ & $0.0022(4)$ & $-0.0006(4)$ & $0.0010(4)$ & $0.0089(2)$ \\
\hline Si1 & $0.0053(4)$ & $0.0058(4)$ & $0.0065(4)$ & $0.0007(3)$ & $-0.0001(3)$ & $-0.0004(3)$ & $0.0059(2)$ \\
\hline $\mathrm{Si} 2$ & $0.0059(4)$ & $0.0056(4)$ & $0.0067(4)$ & $0.0005(3)$ & $0.0003(3)$ & $0.0000(3)$ & $0.0062(3)$ \\
\hline $\mathrm{O} 11$ & $0.005(1)$ & $0.007(1)$ & $0.0076(9)$ & $0.0010(8)$ & $0.0006(7)$ & $-0.0007(8)$ & $0.0064(4)$ \\
\hline $\mathrm{O} 12$ & $0.008(1)$ & $0.006(1)$ & $0.0084(9)$ & $-0.0004(8)$ & $-0.0009(8)$ & $0.0009(8)$ & $0.0079(4)$ \\
\hline $\mathrm{O} 13$ & $0.005(1)$ & $0.006(1)$ & $0.0091(9)$ & $0.0009(8)$ & $-0.0015(8)$ & $-0.0004(8)$ & $0.0070(4)$ \\
\hline $\mathrm{O} 14$ & $0.006(1)$ & $0.008(1)$ & $0.0079(9)$ & $-0.0009(8)$ & $0.0003(8)$ & $-0.0004(8)$ & $0.0077(3)$ \\
\hline $\mathrm{O} 21$ & $0.006(1)$ & $0.005(1)$ & $0.0074(9)$ & $0.0020((8)$ & $-0.0002(7)$ & $-0.0002(8)$ & $0.0062(4)$ \\
\hline $\mathrm{O} 22$ & $0.007(1)$ & $0.007(1)$ & $0.0098(9)$ & $0.0011(8)$ & $0.0006(8)$ & $-0.0008(8)$ & $0.0079(4)$ \\
\hline $\mathrm{O} 23$ & $0.006(1)$ & $0.008(1)$ & $0.0087(9)$ & $0.0020(8)$ & $0.0003(8)$ & $-0.0015(8)$ & $0.0076(4)$ \\
\hline $\mathrm{O} 24$ & $0.007(1)$ & $0.008(1)$ & $0.0080(9)$ & $0.0014(8)$ & $-0.0001(8)$ & $-0.0007(8)$ & $0.0077(4)$ \\
\hline $\mathrm{OFOH}$ & $0.020(1)$ & $0.008(1)$ & $0.021(1)$ & $0.0037(9)$ & $0.011(1)$ & $0.0014(9)$ & $0.0160(5)$ \\
\hline
\end{tabular}

\section{Results and discussion}

Raman spectroscopy

Unpolarized Raman spectra of OH-clinohumites SZ0407B and SZ041B are shown in Fig. 2, along with a spectrum of coexisting OH-chondrodite from run SZ0407B for comparison. Because the Raman spectra of $\mathrm{OH}$-clinohumite and $\mathrm{OH}$-chondrodite are very similar, and nearly identical in the $\mathrm{OH}$-stretching region (Fig. 2), the most distinguishing difference occurs between 800 and $900 \mathrm{~cm}^{-1}$, where $\mathrm{OH}$-clinohumite has three strong bands and $\mathrm{OH}$ chondrodite only displays one strong band. In Fig. 3, we identify the major difference between pure-Mg and
Fe-bearing $\mathrm{OH}$-clinohumite as the presence of a strong band pair at 650 and $690 \mathrm{~cm}^{-1}$ in the Fe-bearing sample, and therefore likely associated with $\mathrm{Fe}-\mathrm{O}$ lattice vibrational modes. In Fig. 4, we compare the spectra of pure- $\mathrm{Mg}$ and Fe-bearing $\mathrm{OH}$-clinohumites in the $780-1,000 \mathrm{~cm}^{-1}$ range. For each composition, unpolarized spectra are shown for two different, roughly orthogonal directions, that is, the laser is focused on surfaces roughly 90-degrees apart, called orientation 1 (OR1) and orientation 2 (OR2) to illustrate some variability with direction. Aside from differences in band intensities with orientation, the spectra are similar with vibrational band positions identical within error between pure-Mg and Fe-bearing $\mathrm{OH}$-clinohumite. Fig. 5a illustrates Raman spectra for the $\mathrm{OH}$-clinohumite 


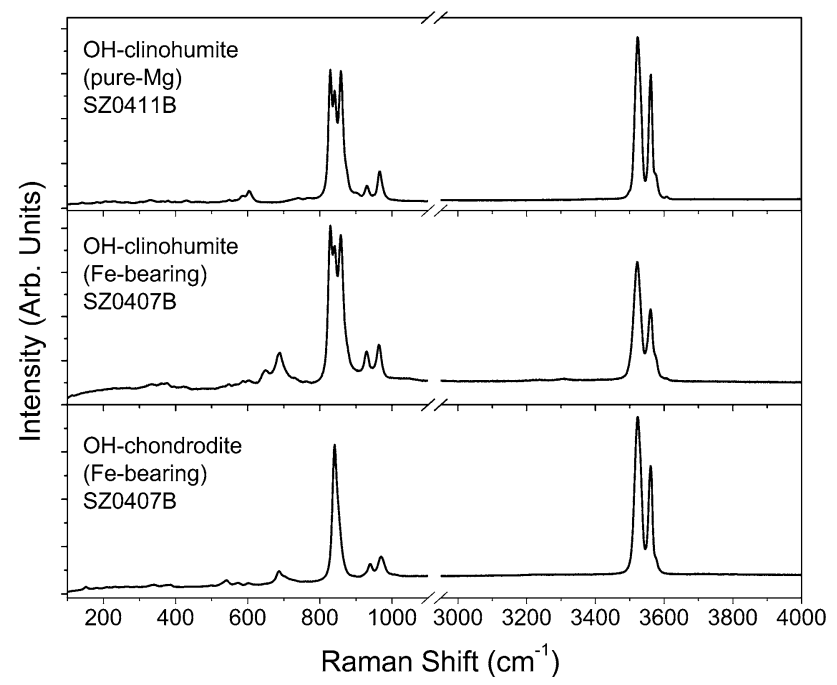

Fig. 2 Comparison of unpolarized Raman spectra for pure-Mg $\mathrm{OH}$-clinohumite (top panel), Fe-bearing $\mathrm{OH}$-clinohumite (middle panel), and $\mathrm{OH}$-chondrodite (bottom panel) coexisting with $\mathrm{OH}$-clinohumite from run SZ0407B

samples in the $\mathrm{OH}$-stretching region. Peaks in the $\mathrm{OH}$ stretching region for the $\mathrm{Mg}$-pure sample agree with those reported by Lin et al. (2000), who observed two strong bands at 3,527 and 3,564 $\mathrm{cm}^{-1}$. The two primary $\mathrm{OH}$ peaks in our spectra occur at about 3,522 and $3,560 \mathrm{~cm}^{-1}$. Also in agreement with Lin et al. (2000), the spectra show a shoulder on the 3,560 band at about $3,575 \mathrm{~cm}^{-1}$, and there is a minor band at $3,608 \mathrm{~cm}^{-1}$, also reported by Lin et al. (2000) at $3,610 \mathrm{~cm}^{-1}$. The position of these bands is also consistent with $\mathrm{OH}$-stretching spectra measured by FTIR spectroscopy (Liu et al. 2003). In addition to these four main $\mathrm{OH}$ bands, we observe a weak band at about $3,500 \mathrm{~cm}^{-1}$, most easily seen in OR1 of the Fe-bearing sample SZ0407B (Fig. 5a).

In Fig. 5b, c, we show deconvolution of the Raman spectra in the $\mathrm{OH}$-stretching region for samples SZ0411B and SZ0407B, respectively. The need for a second peak in the $3,522 \mathrm{~cm}^{-1}$ band is best seen in Fig. 5a for the pureMg sample, where an asymmetry is observed on the highwavenumber side of the $3,522 \mathrm{~cm}^{-1}$ peak. For this main band, we fitted a pair of peaks at 3,523 and $3,533 \mathrm{~cm}^{-1}$ for the pure-Mg sample (Fig. 5b) and a band pair at 3,520 and $3,532 \mathrm{~cm}^{-1}$ in the Fe-bearing sample (Fig. 5c). Although the resolution of these spectra is about $1 \mathrm{~cm}^{-1}$, the small shift of a few wavenumbers for the $3,522 \mathrm{~cm}^{-1} \mathrm{OH}$ band for the Fe-bearing sample is clearly seen in the stacking of the spectra in Fig. 5a. In total, we resolve seven $\mathrm{OH}$-stretching bands for $\mathrm{Mg}$ and $\mathrm{Fe}$-bearing $\mathrm{OH}$-clinohumites, located at about 3,500, 3,522, 3,533, 3,555, 3,562, 3,575 , and $3,608 \mathrm{~cm}^{-1}$.

\section{Crystal structure}

Based on the refined occupancies of cations in sample SZ0407B in Table 3, Fe/(Fe $+\mathrm{Mg})=4.5 \mathrm{~mol} \%$ in $\mathrm{M} 3$ site, compared to about $3 \%$ in the other $\mathrm{M}$ sites. On average, $\mathrm{Fe} /(\mathrm{Fe}+\mathrm{Mg})=3.6 \%$ from X-ray intensity scan, which is slightly smaller than $4.1 \%$ obtained from electron microprobe analyses in the previous discussion (Table 1). Robinson et al. (1973) reported lower Fe contents in the M3 site for F-bearing clinohumite (Fe $\%=5.6 \%$ and $\mathrm{F} \%=5.8 \%$ ) and higher $\mathrm{Fe}$ content in
Fig. 3 Comparison of unpolarized Raman spectra between Mg-pure and Fe-bearing $\mathrm{OH}$-clinohumite. The laser was focused on two roughly perpendicular surfaces for orientation 1 (OR1) and orientation 2 (OR2). The major difference in the Fe-bearing $\mathrm{OH}$-clinohumite sample is the appearance of the band pair at 650 and $690 \mathrm{~cm}^{-1}$

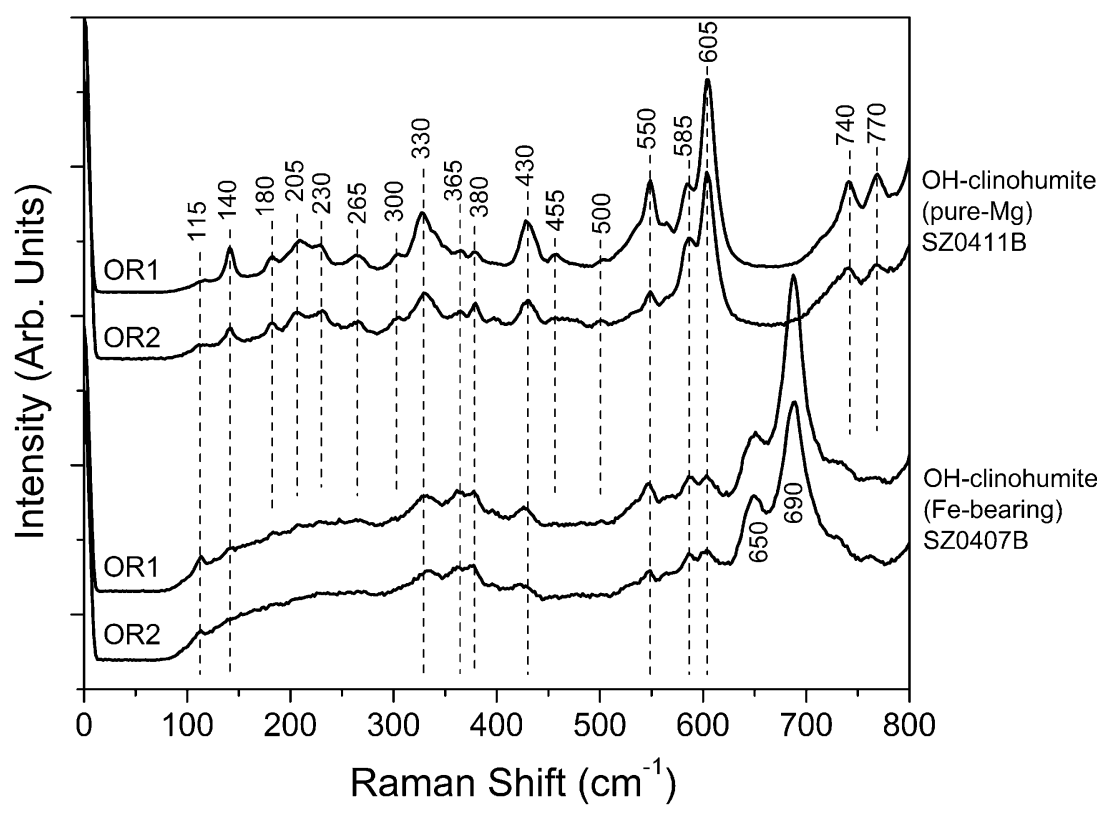




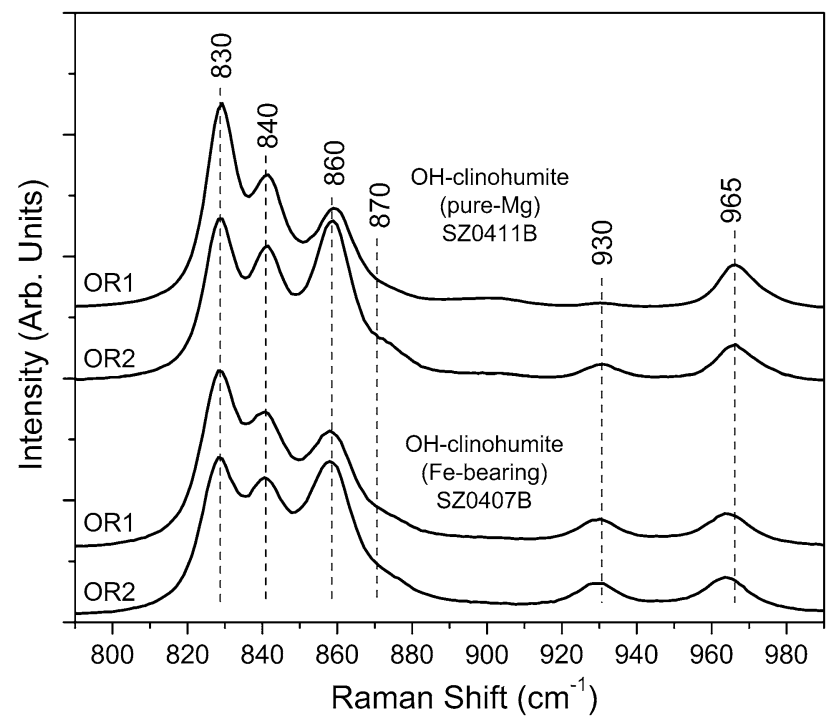

Fig. 4 Comparison of unpolarized Raman spectra between $\mathrm{Mg}$-pure and $\mathrm{Fe}$-bearing $\mathrm{OH}$-clinohumite in the $800-1,000 \mathrm{~cm}^{-1}$ region for two different orientations of the sample

M3 site with almost equal Ti distribution in each octahedral site for F-free titano-clinohumite. On the other hand, Fujino and Takéuchi (1978) and Friedrich et al. (2001) indicate nearly equal distribution of Fe among the octahedral sites, but most of the Ti concentrated in the M3 site for their titano-clinohumite samples $(\mathrm{Fe} \% \approx 12 \%$ and $\mathrm{Ti}$ $\% \approx 5 \%)$. Since Ti appears to order into M3, it is likely that the slight excess of Fe in M3 observed in SZ0407B may be due to a small amount of ferric iron as oxygen fugacity was not tightly controlled during the synthesis experiment. The refined $\mathrm{Si} 1$ and $\mathrm{Si} 2$ occupancies for SZ0407B are very close to those from SZ0411B (Mg-pure sample), and the $\mathrm{Si}$ occupancies in both samples are slightly less than one.

The bond lengths and volumes of cation polyhedra for the current samples were calculated using the software package XTALDRAW (Downs et al. 1993) and are listed in Table 5. The most significant differences in bond lengths between these two samples are as follows: M1C-O14, M1n-O13, $\mathrm{M} 25-\mathrm{O} 24, \mathrm{M} 26-\mathrm{O} 14$, and M3-O21 bond lengths from SZ0407B are 0.06, 0.07, 0.06, 0.06, and $0.010 \AA$ longer than those from SZ0411B, respectively, consistent with higher ferrous iron contents. The two M3-OFOH bond lengths of SZ0407B are 0.011 and $0.008 \AA$ shorter than those of SZ0411B, respectively, consistent with a small amount of ferric iron ordering into M3. Berry and James (2001) gave $\mathrm{OF}-\mathrm{D} 1=1.07(2) \AA$ and $\mathrm{OF}-\mathrm{D} 2=1.08(2) \AA$ for Mg-pure deuterated hydroxyl-clinohumite by powder neutron diffraction, while the current single-crystal X-ray diffraction studies show OF-H1 bond lengths of 0.99(6) $\AA$ for SZ0407B/
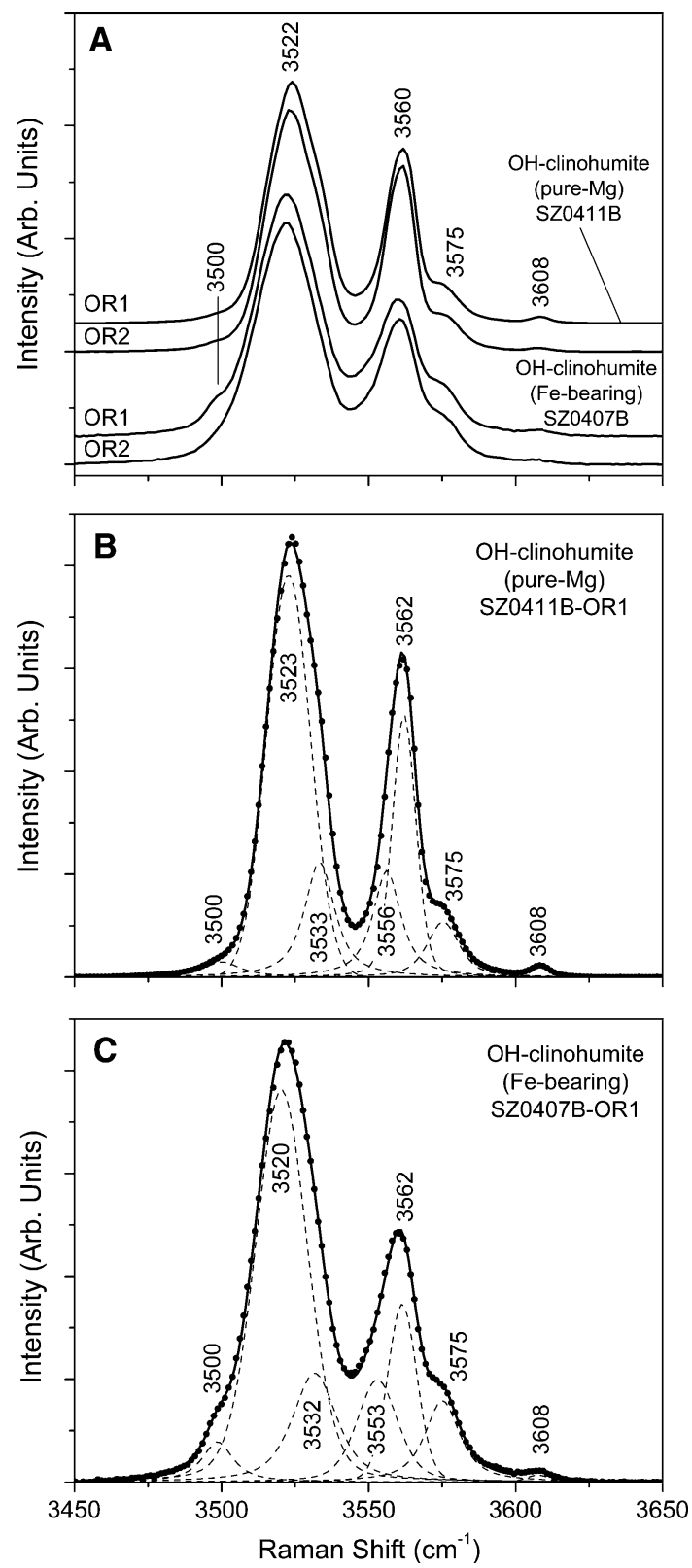

Fig. 5 a Comparison of unpolarized Raman spectra in the $\mathrm{OH}$-stretching region between $\mathrm{Mg}$-pure and $\mathrm{Fe}$-bearing $\mathrm{OH}$-clinohumite for two sample different orientations. Panels $B$ and $C$ illustrate deconvolution of the spectra into seven distinct $\mathrm{OH}$-stretching modes

0.84(6) $\AA$ for SZ0411B; and OF-H2 bond lengths of $1.35(\AA)$ for SZ0407B/1.62(6) $\AA$ for SZ0411B, assuming full occupancies in $\mathrm{H} 1 / \mathrm{H} 2$ sites. The $\mathrm{H}$ atomic positions refined from neutron diffraction better reflect the $\mathrm{O}-\mathrm{H}$ interatomic distances compared with our results from X-ray diffraction.

To compare the effects of $\mathrm{Fe}$, $\mathrm{Ti}$, and $\mathrm{F}$ components on the crystal structure of clinohumite, the selected $\mathrm{M}-\mathrm{O}$ bond 
Table 5 Bond lengths $(\AA)$ and volumes $\left(\AA^{3}\right)$ of cation polyhedra

\begin{tabular}{|c|c|c|c|c|c|}
\hline & SZ0407B & SZ0411B & & SZ0407B & SZ0411B \\
\hline$M 1 C$ & & & M3 & & \\
\hline $\mathrm{O} 11 \times 2$ & $2.093(1)$ & $2.096(2)$ & $\mathrm{O} 21$ & $2.142(1)$ & $2.132(2)$ \\
\hline $\mathrm{O} 12 \times 2$ & $2.075(1)$ & $2.073(2)$ & $\mathrm{O} 22$ & $2.241(1)$ & $2.243(2)$ \\
\hline $\mathrm{O} 14 \times 2$ & $2.135(1)$ & $2.129(2)$ & $\mathrm{O} 24$ & $2.020(1)$ & $2.017(2)$ \\
\hline Avg. bond & $2.101(1)$ & $2.099(2)$ & $\mathrm{O} 24$ & $2.116(1)$ & $2.114(2)$ \\
\hline \multirow[t]{4}{*}{ Poly. $V\left(\AA^{3}\right)$} & $11.90(1)$ & $11.86(2)$ & $\mathrm{OFOH}$ & $2.050(2)$ & $2.061(3)$ \\
\hline & & & $\mathrm{OFOH}$ & $2.072(2)$ & $2.080(3)$ \\
\hline & & & Avg. bond & $2.107(1)$ & $2.108(2)$ \\
\hline & & & Poly. $V\left(\AA^{3}\right)$ & $12.10(1)$ & $12.11(2)$ \\
\hline$M 1 N$ & & & Sil & & \\
\hline O11 & $2.113(1)$ & $2.115(2)$ & $\mathrm{O} 11$ & $1.616(1)$ & $1.614(2)$ \\
\hline $\mathrm{O} 12$ & $2.083(1)$ & $2.083(2)$ & $\mathrm{O} 12$ & $1.659(1)$ & $1.654(2)$ \\
\hline $\mathrm{O} 13$ & $2.126(1)$ & $2.119(2)$ & $\mathrm{O} 13$ & $1.642(1)$ & $1.640(2)$ \\
\hline $\mathrm{O} 21$ & $2.099(1)$ & $2.097(2)$ & $\mathrm{O} 14$ & $1.638(1)$ & $1.637(2)$ \\
\hline $\mathrm{O} 22$ & $2.070(1)$ & $2.067(2)$ & Avg. bond & $1.639((1)$ & $1.636(2)$ \\
\hline $\mathrm{O} 23$ & $2.139(1)$ & $2.138(2)$ & Poly. $V\left(\AA^{3}\right)$ & $2.22(1)$ & $2.21(2)$ \\
\hline Avg. bond & $2.105(1)$ & $2.103(2)$ & & & \\
\hline Poly. $V\left(\AA^{3}\right)$ & $11.95(1)$ & $11.92(2)$ & & & \\
\hline$M 25$ & & & $\mathrm{Si} 2$ & & \\
\hline $\mathrm{O} 13$ & $2.034(1)$ & $2.036(2)$ & $\mathrm{O} 21$ & $1.614(1)$ & $1.613(2)$ \\
\hline $\mathrm{O} 21$ & $2.192(1)$ & $2.193(2)$ & $\mathrm{O} 22$ & $1.646(1)$ & $1.644(2)$ \\
\hline $\mathrm{O} 22$ & $2.067(1)$ & $2.067(2)$ & $\mathrm{O} 23$ & $1.644(1)$ & $1.640(2)$ \\
\hline $\mathrm{O} 23$ & $2.185(1)$ & $2.182(2)$ & $\mathrm{O} 24$ & $1.642(1)$ & $1.642(2)$ \\
\hline $\mathrm{O} 24$ & $2.211(1)$ & $2.205(2)$ & Avg. bond & $1.636(1)$ & $1.635(2)$ \\
\hline $\mathrm{OFOH}$ & $2.066(2)$ & $2.067(3)$ & Poly. $V\left(\AA^{3}\right)$ & $2.22(1)$ & $2.21(2)$ \\
\hline Avg. bond & $2.126(1)$ & $2.125(2)$ & & & \\
\hline Poly. $V\left(\AA^{3}\right)$ & $12.43(1)$ & $12.42(2)$ & & & \\
\hline M26 & & & $H 1$ & & \\
\hline O11 & $2.189(1)$ & $2.184(2)$ & $\mathrm{OFOH}$ & $0.99(6)$ & $0.84(6)$ \\
\hline $\mathrm{O} 12$ & $2.060(1)$ & $2.060(2)$ & $H 2$ & & \\
\hline $\mathrm{O} 13$ & $2.198(1)$ & $2.197(2)$ & $\mathrm{OFOH}$ & $1.37(6)$ & $1.62(6)$ \\
\hline O14 & $2.243(1)$ & $2.237(2)$ & & & \\
\hline O14 & $2.058(1)$ & $2.060(2)$ & & & \\
\hline $\mathrm{O} 23$ & $2.074(1)$ & $2.075(2)$ & & & \\
\hline Avg. bond & $2.137(1)$ & $2.136(2)$ & & & \\
\hline Poly. $V\left(\AA^{3}\right)$ & $12.53(1)$ & $12.50(2)$ & & & \\
\hline
\end{tabular}

lengths for samples of this and previous studies are summarized in Table 6. Ti has the most significant contribution to increasing the $\alpha$ angle (e, f, and g), while $\mathrm{F}$ decreases the unit-cell volumes most significantly ( $\mathrm{d}$ and $\mathrm{h}$ ). The most significant effect of these elements on $\mathrm{M}-\mathrm{O}$ bond lengths is the decreasing in M3-OF lengths. The M3-OF bond lengths decrease in the order of $\mathrm{a}, \mathrm{c}>\mathrm{b}>\mathrm{g}>\mathrm{h}, \mathrm{d}>\mathrm{e}, \mathrm{f}(\mathrm{Mg}$ $\%=100 \%$ and $\mathrm{Ti} \%=0$ for a and $\mathrm{c} ; \mathrm{Fe} \% \sim 12 \%$ and $\mathrm{Ti}$ $\% \sim 5 \%$ for e and $\mathrm{f}$ ), consistent with the radius of $\mathrm{Mg}^{2+}$ being larger than those of $\mathrm{Fe}^{3+}$ and $\mathrm{Ti}^{4+}$. Consequently, $\langle\mathrm{M} 3-\mathrm{O}\rangle$ bond lengths for samples $\mathrm{d}$, e, f, g, and $\mathrm{h}$ are $\sim 0.02 \AA$ smaller than those of samples a and $\mathrm{c}$, due to the shortened M3-OF lengths. $\langle\mathrm{M} 2-5-\mathrm{O}\rangle$ lengths of samples e and $\mathrm{f}$ are $\sim 0.01 \AA$ larger than those of the other samples,

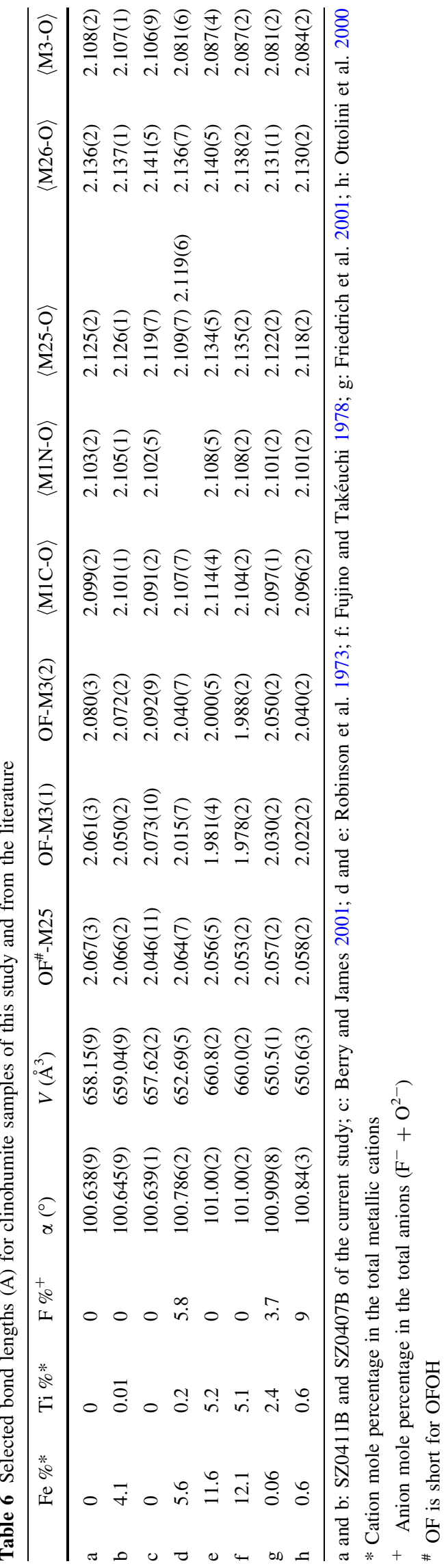



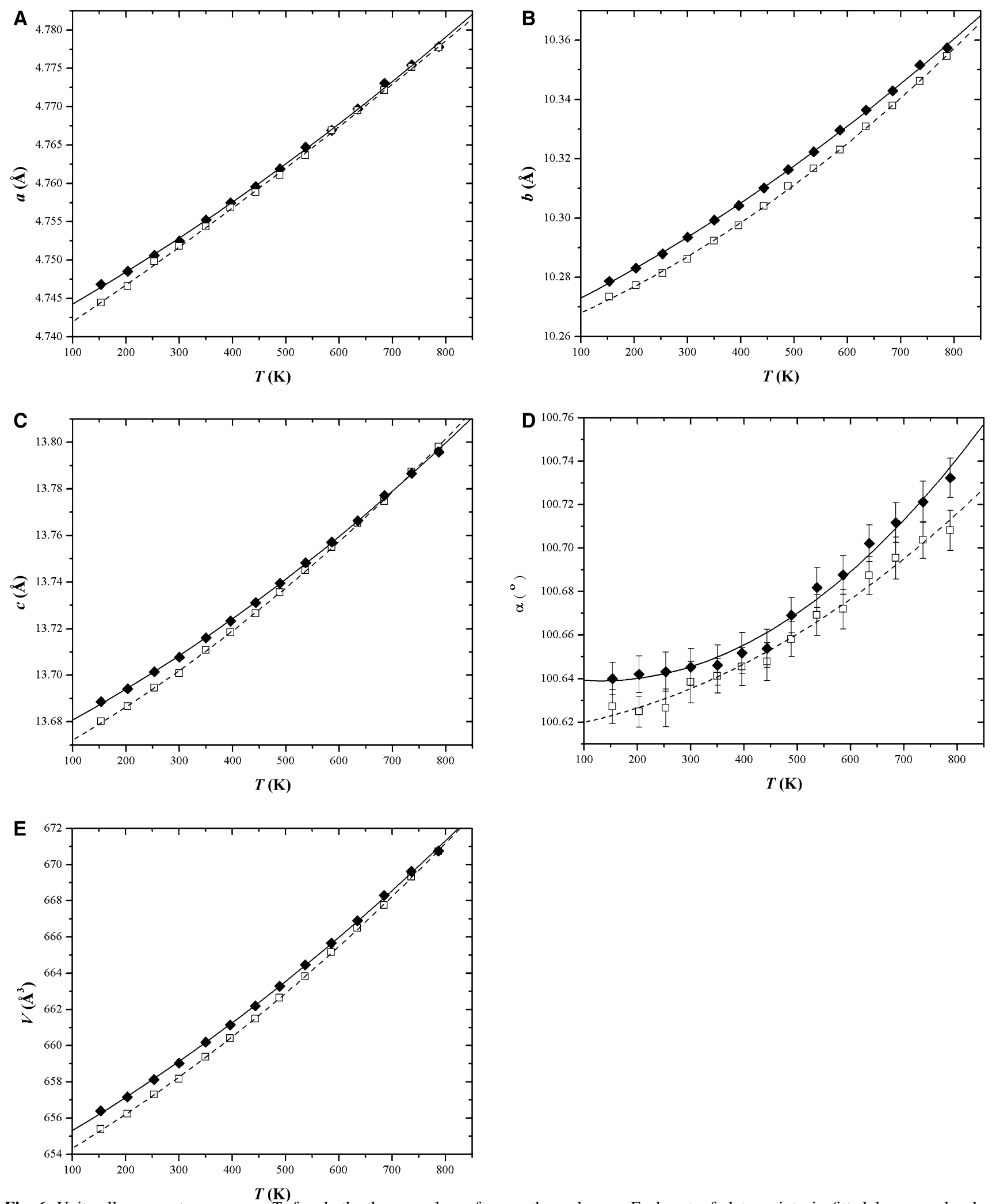

Fig. 6 Unit-cell parameters versus $T$ for both the samples of SZ0407B (solid diamond) and SZ0411B (open square). a-c the axes;

e the volumes. Each set of data points is fitted by second-order polynomial curve (solid SZ0407B; dash SZ0411B) 


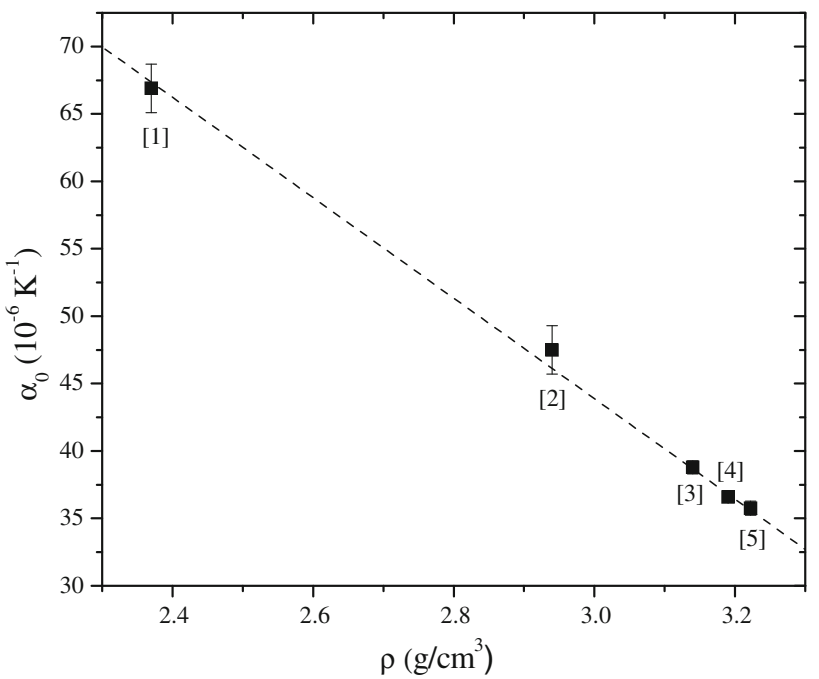

Fig. 7 Plot of average thermal expansion coefficient versus density for DHMS phases along the forsterite-brucite. [1] brucite, Fukui et al. (2003); [2] phase A, Pawley et al. (1995); [3] clinohumite, the current sample of SZ0411B; [4] clinohumite, the current sample of SZ0407B; [5] anhydrous forsterite, Ye et al. (2009). The temperature ranges are as follows: $299-593 \mathrm{~K}$ for Point [1]; 293-873 $\mathrm{K}$ for Point [2]; 300-787 K for Points [3-5]

consistent with higher contents of larger cations $\left(\mathrm{Fe}^{2+}\right)$ and no OF atoms coordinating with the M2-5 site. There are no significant differences for other $\langle\mathrm{M}-\mathrm{O}\rangle$ lengths among the samples.

\section{Thermal expansion}

The unit-cell parameters $a, b, c, \alpha$, and $V$ versus temperature are plotted in Fig. 6a-e, respectively, with second-order polynomial fitting for each data set. The calculated bulk, axial, and $\alpha$ angle thermal expansion coefficients are summarized in Table 7. Both samples show anisotropy of thermal expansion in the order of $\alpha_{c}>\alpha_{b}>\alpha_{a}$, while Ross and Crichton (2001) concluded the anisotropy of compressibility as $\beta_{b}>\beta_{c}>\beta_{a}$ for Mg-pure synthetic clinohumite. The $\alpha$ angles increase as temperature increases, especially above $450 \mathrm{~K}$.

Prior studies of thermal expansivity of other DHMS phases along the brucite-forsterite join were reported for brucite (Fukui et al. 2003), Phase A (Pawley et al. 1995) and forsterite (Ye et al. 2009; and Smyth and Hazen 1973). The average thermal expansion coefficients $\left(\alpha_{0}\right)$ for these phases are summarized in Fig. 7, as a function of density. The linear regression gives a systematic relation with density:

$$
\alpha_{0}(V)\left(10^{-6} \mathrm{~K}^{-1}\right)=156(7)-37(2) \times \rho\left(\mathrm{g} / \mathrm{cm}^{3}\right)
$$

The negative slope of this regression is consistent with the positive slope of linear regression for isothermal bulk modulus $\left(K_{T}\right)$ versus density (Ross and Crichton 2001 and Holl et al. 2006). The Points [1, 2, 3 and 5] are Mg-pure phases, and Point [4] has a Fe $\%$ of $\sim 4 \%$, indicating that the $\alpha_{0}(V)$ versus $\rho$ relationship appears to hold for at least some Fe-bearing phases such as clinohumite.

After heating to $787 \mathrm{~K}$, each sample was cooled to room temperature to refine the unit-cell parameters again: $a=4.7514(4) \AA, \quad b=10.293(1) \AA, \quad c=13.7045(9) \AA$, $\alpha=100.648(9)^{\circ}, \quad V=658.71(9) \AA^{3}$ for SZ0407B; $a=4.7513(6) \AA, \quad b=10.287(1) \AA, \quad c=13.7000(9) \AA$, $\alpha=100.632(9)^{\circ}, V=658.15(9) \AA^{3}$ for SZ0411B, which are consistent with the initial unit-cell parameters before heating. In conclusion, both the single crystals of Mg-pure and Fe-bearing clinohumite persist to $787 \mathrm{~K}$ at ambient pressure, without significant phase transition or dehydration. In addition, Pawley et al. (1995) reported that the structure of Phase A persists to $873 \mathrm{~K}$, and Ye et al. (2009)
Table 7 Bulk, axial, and $\alpha$ angle thermal expansion coefficients

\begin{tabular}{|c|c|c|c|c|c|}
\hline & \multicolumn{3}{|l|}{$\alpha=a_{1} * T+a_{0}$} & \multicolumn{2}{|l|}{$\alpha=\alpha_{0}$} \\
\hline & $a_{1}\left(10^{-9} \mathrm{~K}^{-2}\right)$ & $a_{0}\left(10^{-6} \mathrm{~K}^{-1}\right)$ & $R^{2}$ & $\alpha_{0}\left(10^{-6} \mathrm{~K}^{-1}\right)$ & $R^{2}$ \\
\hline \multicolumn{6}{|c|}{$S Z 0407 B$} \\
\hline$V$ & $21.4(19)$ & $24.8(10)$ & 0.9997 & $34.9(5)$ & 0.9967 \\
\hline$a$ & $5.5(10)$ & $7.9(4)$ & 0.9992 & $10.5(1)$ & 0.9970 \\
\hline$b$ & $8.5(8)$ & $8.3(4)$ & 0.9996 & $12.3(2)$ & 0.9959 \\
\hline$c$ & $9.0(7)$ & $8.3(4)$ & 0.9997 & $12.5(2)$ & 0.9957 \\
\hline$\alpha$ & $4.6(6)$ & $-0.6(3)$ & 0.9845 & $1.53(13)$ & 0.9157 \\
\hline \multicolumn{6}{|c|}{$S Z 0411 B$} \\
\hline$V$ & $25.4(13)$ & $24.9(6)$ & 0.9999 & $36.8(6)$ & 0.9962 \\
\hline$a$ & $3.0(9)$ & $9.7(4)$ & 0.9994 & 11.1(1) & 0.9988 \\
\hline$b$ & $12.4(9)$ & $6.7(4)$ & 0.9995 & $12.6(3)$ & 0.9920 \\
\hline$c$ & $10.2(3)$ & $8.9(3)$ & 0.9998 & 13.7(3) & 0.9955 \\
\hline$\alpha$ & $2.4(4)$ & $0.3(3)$ & 0.9848 & $1.41(8)$ & 0.9632 \\
\hline
\end{tabular}


reported the persistence of hydrous forsterite $(0.89 \mathrm{wt} \%$ $\mathrm{H}_{2} \mathrm{O}$ ) up to $919 \mathrm{~K}$, also at ambient pressure.

The volume thermal expansion, $\alpha_{0}(V)$, for sample SZ0407B is about $2 \times 10^{-6} \mathrm{~K}^{-1}$ smaller than that for SZ0411B, indicating that a $1 \mathrm{~mol} \%$ increase in Fe content decreases the thermal expansivity by about $1.3 \%$, compared with Mg-pure clinohumite. Smyth and Hazen (1973) and Smyth (1975) demonstrated that $\mathrm{Fe}$ decreases the thermal expansivity of olivine. In addition, extensive high-pressure studies supported that $\mathrm{Fe}$ decreases the compressibilities or increases the isothermal bulk moduli of the silicates in the upper mantle and transition zone, such as Phase A (Crichton and Ross 2002; Holl et al. 2006), olivine (Zhang 1998), wadsleyite (Hazen et al. 1990), ringwoodite (Hazen 1993), and garnet (Hazen et al. 1994).

In summary, we have studied the high-temperature crystal chemistry of two hydroxyl-clinohumite: one pure$\mathrm{Mg}$ sample and one with $\mathrm{Fe} /(\mathrm{Fe}+\mathrm{Mg})$ of about $4 \mathrm{~mol} \%$. Synthesis conditions for both compositions were $12 \mathrm{GPa}$ and $1,250{ }^{\circ} \mathrm{C}$, corresponding to conditions near $360 \mathrm{~km}$ depth in a hydrous subducting slab. Refinement of the crystal structures at ambient conditions shows a small volume increase in octahedral cation sites M1c, M1n, M2-5, and M2-6 consistent with ferrous iron substitution into these sites and a slight volume decrease in M3 consistent with a small amount of ferric iron ordering into this site. We have measured thermal expansion of these two samples from 157 to $787 \mathrm{~K}$ and observe a small decrease in expansivity with iron substitution. Comparing thermal expansivity with other DHMS phases on the forsteritebrucite join, we derive a systematic relationship of thermal expansivity with density consistent with previous observation of a systematic variation of compressibility with density.

Acknowledgments This work was supported by US National Science Foundation grant EAR 11-13369 to JRS. SDJ acknowledges support from the NSF EAR-0748707 (CAREER), the Carnegie/DOE Alliance Center (CDAC), and by the David and Lucile Packard Foundation. Syntheses were performed at Bayerisches Geoinstitut, University of Bayreuth, Germany, and supported in part by the Alexander von Humboldt Foundation.

\section{Appendix}

See Table 8 .
Table 8 Unit-cell parameters as functions of temperature for both samples SZ0407B and SZ0411B

\begin{tabular}{llllll}
\hline$T(\mathrm{~K})$ & $a(\AA) b$ & $(\AA)$ & $c(\AA)$ & $\alpha\left({ }^{\circ}\right)$ & $V\left(\AA^{3}\right)$ \\
\hline SZ0407B & & & & & \\
$153(2)$ & $4.7468(4)$ & $10.279(1)$ & $13.6887(8)$ & $100.641(8)$ & $656.40(8)$ \\
$203(2)$ & $4.7485(4)$ & $10.283(1)$ & $13.6942(9)$ & $100.643(8)$ & $657.17(8)$ \\
$253(2)$ & $4.7506(4)$ & $10.288(1)$ & $13.7015(9)$ & $100.643(9)$ & $658.13(8)$ \\
$300(2)$ & $4.7525(4)$ & $10.294(1)$ & $13.7077(9)$ & $100.645(9)$ & $659.04(9)$ \\
$350(2)$ & $4.7552(4)$ & $10.299(1)$ & $13.7161(9)$ & $100.646(9)$ & $660.19(9)$ \\
$396(3)$ & $4.7575(4)$ & $10.304(1)$ & $13.7232(9)$ & $100.652(9)$ & $661.15(9)$ \\
$443(3)$ & $4.7596(4)$ & $10.310(1)$ & $13.7312(9)$ & $100.654(9)$ & $662.20(8)$ \\
$489(3)$ & $4.7619(4)$ & $10.316(1)$ & $13.7395(9)$ & $100.669(8)$ & $663.28(8)$ \\
$537(4)$ & $4.7647(4)$ & $10.322(1)$ & $13.7482(9)$ & $100.682(9)$ & $664.46(9)$ \\
$586(4)$ & $4.7669(4)$ & $10.330(1)$ & $13.7571(9)$ & $100.688(9)$ & $665.66(8)$ \\
$635(4)$ & $4.7697(4)$ & $10.336(1)$ & $13.7664(9)$ & $100.702(8)$ & $666.90(8)$ \\
$685(4)$ & $4.7731(4)$ & $10.343(1)$ & $13.7772(9)$ & $100.712(9)$ & $668.29(9)$ \\
$736(5)$ & $4.7754(4)$ & $10.352(1)$ & $13.7866(9)$ & $100.721(9)$ & $669.62(9)$ \\
$787(5)$ & $4.7778(4)$ & $10.357(1)$ & $13.7958(9)$ & $100.732(9)$ & $670.75(9)$ \\
$S Z 0411 B$ & & & & & \\
$153(2)$ & $4.7444(6)$ & $10.273(1)$ & $13.6802(8)$ & $100.627(8)$ & $655.39(9)$ \\
$203(2)$ & $4.7466(5)$ & $10.277(1)$ & $13.6866(9)$ & $100.625(7)$ & $656.23(8)$ \\
$253(2)$ & $4.7498(6)$ & $10.281(1)$ & $13.6946(9)$ & $100.627(9)$ & $657.30(9)$ \\
$300(2)$ & $4.7518(6)$ & $10.286(1)$ & $13.7008(9)$ & $100.638(9)$ & $658.15(9)$ \\
$350(2)$ & $4.7544(5)$ & $10.292(1)$ & $13.7108(9)$ & $100.641(8)$ & $659.38(9)$ \\
$396(3)$ & $4.7568(6)$ & $10.297(1)$ & $13.7185(9)$ & $100.646(9)$ & $660.41(9)$ \\
$443(3)$ & $4.7588(6)$ & $10.304(1)$ & $13.7265(9)$ & $100.648(9)$ & $661.49(9)$ \\
$489(3)$ & $4.7610(5)$ & $10.311(1)$ & $13.7355(9)$ & $100.658(8)$ & $662.64(9)$ \\
$537(4)$ & $4.7636(6)$ & $10.317(1)$ & $13.7450(9)$ & $100.669(9)$ & $663.82(9)$ \\
$586(4)$ & $4.7669(6)$ & $10.323(1)$ & $13.7549(9)$ & $100.672(9)$ & $665.16(9)$ \\
$635(4)$ & $4.7695(6)$ & $10.331(1)$ & $13.7653(9)$ & $100.687(9)$ & $666.49(9)$ \\
$685(4)$ & $4.7721(7)$ & $10.338(1)$ & $13.7747(9)$ & $100.695(9)$ & $667.76(9)$ \\
$736(5)$ & $4.7752(6)$ & $10.346(1)$ & $13.7874(9)$ & $100.704(8)$ & $669.31(9)$ \\
$787(5)$ & $4.7777(6)$ & $10.355(1)$ & $13.7980(9)$ & $100.708(9)$ & $670.72(9)$ \\
\hline & & & & &
\end{tabular}

\section{References}

Berry AJ, James M (2001) Refinement of hydrogen positions in synthetic hydroxyl-clinohumite by powder neutron diffraction. Am Mineral 86:181-184

Crichton WA, Ross NL (2002) Equation of state of dense hydrous magnesium silicate phase $\mathrm{A}, \mathrm{Mg}_{7} \mathrm{Si}_{2} \mathrm{O}_{8}(\mathrm{OH})_{6}$. Am Mineral 87:333-338

Cromer DT, Mann J (1968) X-ray scattering factors computed from numerical Hartree-Fock wave functions. Acta Crystallogr A24:321-325 
Downs RT, Bartelmehs KL, Gibbs GV, Boisen MB (1993) Interactive software for calculating and displaying X-ray or neutron powder diffractometer patterns of crystalline materials. Am Mineral 78:1104-1107

Farrugia LJ (1999) WinGX software package. J Appl Crystallogr 32:837-838

Faust J, Knittle E (1994) Static compression of chondrodite: implications for water in the upper mantle. Geophys Res Lett 21:1935-1938

Ferraris G, Prencipe M, Sokolova E, Gekimyants VM, Spiridonov E (2000) Hydroxyl-clinohumite a new member of the humite group: twinning, crystal structure and crystal chemistry of the clinohumite subgroup. Z für Krist 215:169-174

Friedrich A, Lager GA, Kunz M, Chakoumakos BC, Smyth JR, Schultz AJ (2001) Temperature-dependent single-crystal neutron diffraction study of natural chondrodite and clinohumite. Am Mineral 86:981-989

Fujino K, Takéuchi Y (1978) Crystal chemistry of titanian chondrodite and titanian clinohumite of high-pressure origin. Am Mineral 63:535-543

Fukui T, Ohtaka O, Suziki T, Funakoshi K (2003) Thermal expansion of $\mathrm{Mg}(\mathrm{OH})_{2}$ brucite under high pressure and pressure dependence of entropy. Phys Chem Miner 30:511-516

Hazen RM (1993) Comparative compressibilities of silicate spinels: anomalous behavior of $(\mathrm{Mg}, \mathrm{Fe})_{2} \mathrm{SiO}_{4}$. Science 259:206-209

Hazen RM, Zhang J, Ko J (1990) Effects of Fe/Mg on the compressibility of synthetic wadsleyite: $\beta-\left(\mathrm{Mg}_{1-\mathrm{x}} \mathrm{Fe}_{\mathrm{x}}\right)_{2} \mathrm{SiO}_{4}$ $(\mathrm{x} \leq 0.25)$. Phys Chem Miner 17:416-419

Hazen RM, Downs RT, Conrad PG, Finger LW, Gasparik T (1994) Comparative compressibilities of majorite-type garnets. Phys Chem Miner 21:344-349

Holl CM, Smyth JR, Manghnani MH, Amulele GM, Sekar M, Frost DJ, Prakapenka VB, Shen G (2006) Crystal structure and compression of an iron-bearing Phase A to $33 \mathrm{GPa}$. Phys Chem Miner 33:192-199

Kanzaki M (1991) Stability of hydrous magnesium silicates in the mantle transition zone. Phys Earth Planet Inter 66:307-312

Lin CC, Liu LG, Mernagh TP, Irifune T (2000) Raman spectroscopic study of hydroxyl-clinohumite at various pressures and temperatures. Phys Chem Miner 27:320-331

Liu Z, Lager GA, Hemley RJ, Ross NL (2003) Synchrotron infrared spectroscopy of $\mathrm{OH}$-chondrodite and $\mathrm{OH}$-clinohumite at high pressure. Am Mineral 88:1412-1415

McGetchin TR, Silver LT, Chodos AA (1970) Titanoclinohumite: a possible mineralogical site for water in the upper mantle. J Geophys Res 75:255-259

Ottolini L, Cámara F, Bigi S (2000) An investigation of matrix effects in the analysis of fluorine in humite-group minerals by EMPA, SIMS, and SREF. Am Mineral 85:89-102
Pawley AR, Redfern SAT, Wood BJ (1995) Thermal expansivities and compressibilities of hydrous phases in the system MgO$\mathrm{SiO}_{2}-\mathrm{H}_{2} \mathrm{O}$ : talc, phase A and 10- $\mathrm{A}$ phase. Contrib Mineral Petrol 122:301-307

Robinson K, Gibbs GV, Ribbe PH (1973) The crystal structure of the humite minerals IV. Clinohumite and Titanoclinohumite. Am Mineral 58:43-49

Ross NL, Crichton WA (2001) Compression of synthetic hydroxylclinohumite $\left[\mathrm{Mg}_{9} \mathrm{Si}_{4} \mathrm{O}_{16}(\mathrm{OH})_{2}\right]$ and hydroxylchondrodite $\left[\mathrm{Mg}_{5} \mathrm{Si}_{2} \mathrm{O}_{8}(\mathrm{OH})_{2}\right]$. Am Mineral 86:990-996

Sanchez-valle C, Sinogeikin SV, Smyth JR, Bass JD (2006) Singlecrystal elastic properties of dense hydrous magnesium silicate phase A. Am Mineral 91:961-964

Sheldrick GM (1997) SHELXL97, Release 97-2. Program for the refinement of crystal structures. University of Göttingen, Germany

Smyth JR (1975) The high temperature crystal chemistry of fayalite. Am Mineral 60:1092-1097

Smyth JR, Hazen RM (1973) The crystal structure of forsterite and hortonolite at several temperatures up to $900^{\circ} \mathrm{C}$. Am Mineral 58:588-593

Smyth JR, Frost DJ, Nestola F, Holl CM, Bromiley G (2006) Olivine hydration in the deep upper mantle: effects of temperature and silica activity. Geophys Res Lett 33:L15301

Tokonami M (1965) Atomic scattering factor for $\mathrm{O}^{2-}$. Acta Crystallogr 19:486

Wunder B (1998) Equilibrium experiments in the system $\mathrm{MgO}-\mathrm{SiO}_{2}-$ $\mathrm{H}_{2} \mathrm{O}$ (MSH): stability fields of clinohumite-OH $\left[\mathrm{Mg}_{9} \mathrm{Si}_{4} \mathrm{O}_{16}\right.$ $\left.(\mathrm{OH})_{6}\right]$, chondrodite-OH $\left[\mathrm{Mg}_{5} \mathrm{Si}_{2} \mathrm{O}_{8}(\mathrm{OH})_{2}\right]$ and phase $\mathrm{A}$ $\left[\mathrm{Mg}_{7} \mathrm{Si}_{2} \mathrm{O}_{8}(\mathrm{OH})_{6}\right]$. Contrib Mineral Petrol 132:111-120

Wunder B, Medenbach O, Daniels P, Schreyer W (1995) Frist synthesis of the hydroxyl end-member of humite, $\mathrm{Mg}_{7} \mathrm{Si}_{3} \mathrm{O}_{12}$ $(\mathrm{OH})_{2}$. Am Mineral 80:638-640

Ye Y, Schwering RA, Smyth JR (2009) Effects of hydration on thermal expansion of forsterite, wadsleyite, and ringwoodite at ambient pressure. Am Mineral 94:899-904

Zhang L (1998) single crystal hydrostatic compression of (Mg, Mn, $\mathrm{Fe}, \mathrm{Co} 2 \mathrm{SiO} 4$ olivines. Phys Chem Miner 25:308-312 